Resenha

\title{
Vida e morte no trabalho
}

\section{DWYER, Tom. Tradução de Wanda Caldeira Brant e Jô Amado. São Paulo: Multiação Editorial/Unicamp, 2006. 408p.}

A Editora da Unicamp e a Multiação Editorial prestam importante serviço ao país com a publicação de Vida e morte no trabalho, de Tom Dwyer, sociólogo e professor da Unicamp. A primeira versão desse livro foi lançada, em inglês, em 1991 e recebeu comentários e resenhas das principais publicações mundiais dedicadas aos temas da Segurança, da Ergonomia e da Sociologia do Trabalho.

A contribuição de Dwyer é resumida pela expressão "acidentes industriais são produzidos por relações sociais”. O autor constrói explicação sociológica para as origens dos acidentes, indo além do olhar tradicional baseado em teorias psicológicas de falhas dos operadores.

A explicação do Professor Tom Dwyer é particularmente importante em nosso país, onde o arcabouço jurídico relativo à segurança praticamente desconsidera aspectos da dimensão sociológica dos acidentes cuja importância, na gênese desses eventos, vem sendo apontada como crescente.

No prefácio à edição brasileira, Maria Elizabeth Antunes Lima conclui:

Isso significa que os profissionais responsáveis pela segurança nos contextos de trabalho devem ser orientados por critérios sociais e seu espaço de atuação deve ter como referência as relações sociais produtoras de acidentes. (p. 7)

A teoria proposta por Dwyer discute as contribuições de relações sociais de recompensa, de comando e de organização que levariam trabalhadores a aceitar altos níveis de risco de acidentes no trabalho.

Em relação à recompensa, Dwyer discute como os incentivos financeiros, o aumento das jornadas de trabalho e as recompensas simbólicas levariam trabalhadores a aceitar riscos maiores, podendo sofrer mais acidentes. Os incentivos financeiros agiriam via intensificação do trabalho; o aumento da duração das jornadas atuaria levando trabalhadores a irem além de suas capacidades físicas; e as recompensas sim- bólicas, incentivando a intensificação e o aumento de jornadas.

No que se refere ao comando, trata das relações de autoritarismo, de desintegração de grupos de trabalho e até da servidão voluntária, levando ao aumento da ocorrência da possibilidade de acidentes. O autoritarismo pode ir da violência explícita às ameaças de punição para diminuir a autonomia dos trabalhadores. A desintegração de grupos de trabalho dificulta a cooperação e a comunicação (trocas) entre integrantes, aumentando o risco de acidentes. A servidão voluntária pode ser conseguida via contratação de trabalhadores extremamente necessitados que aceitem a presença de riscos como parte inevitável do trabalho.

No âmbito organização, inclui as práticas de contratação de pessoal menos qualificado a custo mais baixo, a separação entre concepção e execução do trabalho etc. Este nível inclui relações sociais de subqualificação, rotina e desorganização que levariam à monotonia, à desatenção e à desorganização, aumentando o risco de acidentes.

O ponto crucial da proposta de Dwyer é resumido por Lima:

$$
\begin{aligned}
& \text { é a força do coletivo de trabalhadores, en- } \\
& \text { tendida como o grau em que este coletivo } \\
& \text { consegue exercer seu 'poder de comando', } \\
& \text { que irá influenciar o tratamento a ser dado } \\
& \text { aos perigos presentes no trabalho e, conse- } \\
& \text { qüentemente, o índice de acidentes. (p. 8) }
\end{aligned}
$$

O conteúdo do livro é riquíssimo, fruto de uma cultura muito vasta que vai da história da invenção e uso da lâmpada de Davy, em 1816, à evolução do sentimento da morte no mundo moderno.

A possibilidade da contribuição das Ciências Sociais para a prevenção de acidentes pode encontrar resistências e incompreensões entre profissionais cuja formação é centrada na abordagem de aspectos técnicos de problemas. A teoria de Dwyer não esquece esses incrédulos, que 
só acreditam naquilo que é observável, que pode ser medido, testado e provado com números. $\mathrm{O}$ autor testou sua teoria em sete fábricas da Nova Zelândia e apresenta seus resultados no livro. Posteriormente, orientou pesquisas no Brasil usando a sua teoria. Em outras palavras, sua contribuição não é "mero" exercício teórico. Pelo contrário, reflete o olhar de quem "freqüenta a vida", o chão de fábrica onde se dão os acidentes.

A proposta de Dwyer suscita reflexões e foi alvo de questionamentos que não reduzem a importância de sua contribuição para o campo da Saúde do Trabalhador. Entre os novos estudos que podem ser indicados, um refere-se à exploração da adequação da teoria como explicação do comportamento da acidentalidade no Brasil nos últimos anos. Afinal, à primeira vista, as mudanças ocorridas no mundo do trabalho levaram a reconhecido enfraquecimento da força dos coletivos de trabalhadores, da sua capacidade de exercer o poder de comando capaz de fazer face aos perigos presentes no cotidiano de vida e trabalho. Apesar disso, de acordo com os números oficiais, a acidentalidade caiu significativamente e estabilizou-se nos últimos anos. De acordo com a teoria do autor, o comportamento esperado não seria o aumento dessas taxas?

Para finalizar, nada melhor que as palavras usadas por Lima no encerramento de seu prefácio ao livro:

em um país onde os 'atos inseguros' ainda continuam sendo apontados como os fatores mais importantes na origem dos acidentes, penso que devemos receber com entusiasmo um livro que aborda o problema respeitando sua complexidade e que, acima de tudo, não pretende dar a palavra final sobre o assunto, mas, ao contrário, se apresenta como um estímulo à reflexão e como um convite a novas pesquisas que dêem continuidade a um projeto inegavelmente promissor. (p. 10)

Ildeberto Muniz de Almeida

Professor do Departamento de Saúde Pública da Faculdade de Medicina de Botucatu-SP ialmeida@fmb.unesp.br 